\title{
IMPLEMENTASI KEBIJAKAN PENGELOLAAN BARANG MILIK DAERAH (BMD) PADA PUSKESMAS SUGIHMUKTI KABUPATEN BANDUNG PROVINSI JAWA BARAT
}

\author{
Oleh \\ Melani Pusparani ${ }^{1}$, \\ Sampara Lukman ${ }^{2}$, Devi Irena ${ }^{3}$ \\ ${ }^{1)}$ Program Magister Terapan Studi Pemerintahan Institut Pemerintahan Dalam Negeri \\ melanipusparani19@gmail.com \\ ${ }^{2,3)}$ Institut Pemerintahan Dalam Negeri
}

\begin{abstract}
This study aims to determine the extent to which the implementation of Regional Property (RP) Management can be carried out properly. This research uses a descriptive qualitative approach. The data collection technique used by the writer is data triangulation in the form of observation, interview, and documentation. In addition, it shows that there are inhibiting factors such as missing several bureaucrats who manage goods, inconsistency in communication, reports of doubling of ownership of goods, limited staff, absence of warehouses, multiple employee positions, and administration of goods that are not in accordance with Standard Operating Procedures (SOP). The results showed that the implementation of the Regional Property (RP) Management policy at the Sugihmukti Community Health Center has been running but has not been optimal. This can be seen from the unfulfilled four indicators of policy implementation that refer to Edwards III's theory, showing that first, transmission communication often occurs miss and there is inconsistency in information, secondly regarding sources, namely the non-linearity of $R P$ management. The information shows that there is an error of information in the recording of goods and the fourth is regarding the facilities, namely the absence of dirty warehouses and the absence of SOPs for goods management
\end{abstract}

Keywords: policy implementation, regional property (RP) management

\begin{abstract}
AbSTrak
Denelitian ini bertujuan untuk mengetahui sejauh mana implementasi kebijakan pengelolaan Barang Milik Daerah (BMD) dapat terlaksana dengan baik. Penelitian ini menggunakan pendekatan kualitatif deskriptif. Teknik pengumpulan data yang data yang digunakan penulis yakni triangulasi data berupa observasi, wawancara, dan dokumentasi. Selain itu menunjukkan bahwa adanya faktor penghambat seperti terlewatinya beberapa birokrat pengelola barang, ketidakkonsistenan komunikasi, adanya laporan penggandaan kepemilikan barang, keterbatasan staf, tidak adanya gudang, adanya rangkap jabatan pegawai, dan penatausahaan barang yang tidak sesuai Standar Operasional Prosedur (SOP). Hasil penelitian menunjukkan bahwa implementasi kebijakan pengelolaan Barang Milik Daerah (BMD) pada Puskesmas Sugihmukti sudah berjalan namun belum optimal. Hal ini dapat terlihat dari belum terpenuhinya empat indikator implementasi kebijakan yang mengacu pada teori Edwards III
\end{abstract}


menunjukkan bahwa pertama mengenai komunikasi transmisi sering terjadinya miss dan adanya ketidakkonsistenan informasi yang dapat, kedua mengenai sumber-sumber yakni adanya ketidaklinieran Pendidikan pengelola BMD., ketiga yakni mengenai informasi terlihat adanya kesalahan informasi dalam pencatatan barang dan keempat yakni mengenai fasilitasfasilitas yaitu belum adanya gudang kotor dan belum adanya SOP penatausahaan barang

Kata kunci: implementasi kebijakan, pengelolaan Barang Milik Daerah (BMD)

\section{PENDAHULUAN}

A set atau Barang Milik Daerah (BMD) merupakan salah satu unsur penting dalam rangka penyelenggaraan dalam pemerintahan dan pelayanan kepada masyarakat. BMD merupakan salah satu aset yang paling vital yang dimiliki daerah guna menunjang kegiatan operasional pemerintahan daerah. Hal ini disebabkan dengan adanya Barang Milik Daerah maka pencapaian kegiatan-kegiatan pemerintah dapat terlaksana dengan baik yang nantinya akan meningkatkan indeks kepuasan masyarakat terhadap pemerintah. Oleh karena itu, BMD harus dikelola dengan baik dan benar sehingga terwujud pengelolaan BMD yang transparan, efisien, akuntabel, ekonomis serta menjamin adanya kepastian nilai.

Menurut Soleh dan Rochmansjah (2010: 13) secara sederhana pengelolaan Barang Milik Daerah meliputi tiga fungsi, yaitu: 1) Adanya perencanaan yang tepat; 2) Pelaksanaan dan pemanfaatan secara efektif dan efisien; 3) Pengawasan. Ketiga fungsi tersebut ditunjukkan dalam siklus pengelolaan Barang Milik Daerah. Adapun supaya ketiga fungsi tersebut tercapai, maka diperlukan strategi yang tepat dalam pengelolaan BMD.Kebijakanpemerintahyang tercantum dalam Peraturan Pemerintah No 27 Tahun 2014 tentang Pengelolaan Barang Milik Daerah tentunya harus dilaksanakan dengan baik oleh setiap SKPD (Satuan Kerja Perangkat Daerah) demi terwujudnya akuntabilitas kerja yang efektif dan efisien. Namun pada kenyataannya tidak sedikit SKPD yang dalam pengelolaan BMD-nya masih mengalami beberapa permasalahan, salah satunya pada Puskesmas Sugihmukti Kabupaten Bandung. Pengelolaan aset atau Barang Milik Daerah masih mendapati beberapa permasalahan terlebih pada implementasi atau pelaksanaannya.

Permasalahan pada pengelolaan Barang Milik Daerah bermula ketika pada pada tahap perencanaan BMD banyaknya pengajuanpengajuan barang yang melebihi pagu anggaran. Banyaknya pengajuan-pengajuan yang melebihi anggaran berdasarkan hasil informasi yang didapatkan penulis dari Akuntan Puskesmas Sugihmukti yakni karena terjadinya miss komunikasi antara pihak perencanaan Dinas Kesehatan dengan pengelola BMD di Puskesmas Sugihmukti. Selanjutnya Perencanaan terlihat pada barang yang akan dibelanjakan yang telah dianggarkan pada Rencana Biaya Anggaran (RBA) dengan implementasi di lapangan berbeda. Perbedaan ini dikarenakan perencanaan kebutuhan Barang Milik Daerah yang akan dibelanjakan harus mengacu kepada SSH (Standar Satuan Harga) di mana daftar nama barang, spesifikasi, merk, dan harga barang sudah tercantum di dalamnya dan ini sifatnya baku.

Mengenai permasalahan ini terjadi karena tidak konsistennya komunikasi yang disampaikan, hingga datangnya barang yang dipesan. Ketika Puskesmas Sugihmukti memesan barang melalui Surat Pesanan (SP) yang telah sesuai dengan RBA dan SSH akan tetapi barang yang datang tidak sesuai dengan SP yang disampaikan.

Adapun untuk lebih jelasnya, berikut adalah barang-barang yang tidak sesuai dengan spesifikasi: 
Tabel 1. Daftar Aset Tetap Peralatan dan Mesin yang Tidak Sesuai dengan Surat Pesanan (SP) 2017 - 2019

\begin{tabular}{|c|c|c|c|}
\hline No & Tahun & Nama Barang & Keterangan \\
\hline 1 & 2017 & $\begin{array}{l}\text { 1. Alat Kantor } \\
\text { dan Rumah } \\
\text { Tangga } \\
\text { 2. Alat Studio } \\
\text { dan Alat } \\
\text { Komunikasi } \\
\text { 3. Alat } \\
\text { Laboratorium } \\
\text { 4. Alat } \\
\text { Kedokteran } \\
\text { 5. Alat-alat } \\
\text { Pesenjataan/ } \\
\text { Keamanan }\end{array}$ & $\begin{array}{l}32 \text { sesuai SP } \\
14 \text { tidak sesuai } \\
\text { SP } \\
00 \text { sesuai SP } \\
03 \text { tidak sesuai } \\
\quad \text { SP } \\
15 \text { sesuai SP } \\
00 \text { tidak sesuai } \\
\quad \text { SP } \\
50 \text { sesuai SP } \\
00 \text { tidak sesuai } \\
\text { SP } \\
01 \text { sesuai SP } \\
00 \text { tidak sesuai } \\
\text { SP } \\
\end{array}$ \\
\hline 2 & 2018 & $\begin{array}{l}\text { 6. Alat Kantor } \\
\text { dan Rumah } \\
\text { Tangga } \\
\text { 7. Alat Studio } \\
\text { dan Alat } \\
\text { Komunikasi } \\
\text { 8. Alat } \\
\text { Laboratorium } \\
\text { 9. Alat } \\
\text { Kedokteran } \\
\text { 10. Alat-alat } \\
\text { Persenjataan/ } \\
\text { Keamanan }\end{array}$ & $\begin{array}{l}00 \text { sesuai SP } \\
07 \text { tidak sesuai } \\
\text { SP } \\
00 \text { sesuai SP } \\
00 \text { tidak sesuai } \\
\text { SP } \\
00 \text { sesuai SP } \\
00 \text { tidak sesuai } \\
\text { SP } \\
19 \text { sesuai SP } \\
00 \text { tidak sesuai } \\
\text { SP } \\
00 \text { sesuai SP } \\
00 \text { tidak sesuai } \\
\text { SP }\end{array}$ \\
\hline 3 & 2019 & $\begin{array}{l}\text { 11. Alat Kantor } \\
\text { dan Rumah } \\
\text { Tangga } \\
\text { 12. Alat Studio } \\
\text { dan Alat } \\
\text { Komunikasi } \\
\text { 13. Alat } \\
\text { Laboratorium } \\
\text { 14. Alat } \\
\text { Kedokteran }\end{array}$ & $\begin{array}{l}01 \text { sesuai SP } \\
47 \text { tidak sesuai } \\
\text { SP } \\
01 \text { sesuai SP } \\
00 \text { tidak sesuai } \\
\text { SP } \\
06 \text { sesuai SP } \\
00 \text { tidak sesuai } \\
\text { SP } \\
27 \text { sesuai SP }\end{array}$ \\
\hline
\end{tabular}

\begin{tabular}{ccc}
\hline 2019 & $\begin{array}{c}\text { 15. Alat-alat } \\
\text { Persenjataan/ } \\
\text { Keamanan }\end{array}$ & $\begin{array}{c}00 \text { tidak sesuai } \\
\text { SP }\end{array}$ \\
& & 00 sesuai SP \\
& & 00 tidak sesuai \\
& & SP \\
\hline Sumber: Data & Peralatan dan Mesin Puskesmas \\
& Sugihmukti Kabupaten Bandung 2020
\end{tabular}

Selain itu permasalahan yang terjadi di Puskesmas Sugihmukti yakni pada penggunaan barang yaitu adanya status penggunaan barang ganda pada Sepeda Motor dengan nomor polisi D 5278 S dan D $2727 \mathrm{~V}$ menggunakan Kode Barang 02.03.01.05.0001 Register 0001 dan 0002 tetapi pada laporannya penggunaannya oleh orang yang sama. Namun berbeda dengan implementasi di lapangan bahwasanya salah satu kendaraan telah dipindahtangankan.

Selanjutnya permasalahan yang sering terjadi yakni mengenai penatausahaan bar angimplementasinya penatausahaan barang tidak sesuai SOP sering kali barang yang sudah dipesan dan barang telah ada, langsung didistribusikan tanpa dibuatkan berita acara dan diberikan label terlebih dahulu.

Permasalahan lain yang dialami Puskesmas Sugihmukti dalam pengelolaan Barang Milik Daerah terkendala pada penghapusan barang peralatan dan mesin dengan kondisi rusak berat akan tetapi masih memiliki masa manfaatnya yang dapat dilihat dari tabel berikut.

Tabel 2. Jumlah Aset Tetap pada Daftar Aset Tetap Peralatan dan Mesin pada Puskesmas Sugihmukti Kab. Bandung

\begin{tabular}{cclc}
\hline No & Tahun & $\begin{array}{l}\text { Jumlah } \\
\text { Barang }\end{array}$ & Nilai Barang \\
\hline 1 & 2017 & $\begin{array}{l}118 \\
\text { Barang }\end{array}$ & BMD. 696.721.434,00 \\
& & Bar 89.547.138,00 \\
2 & 2018 & $\begin{array}{l}145 \\
\text { Barang }\end{array}$ & BMD. 890.5 182.482.763,00 \\
3 & 2019 & $\begin{array}{l}241 \\
\text { Barang }\end{array}$ & BMD. 1.18 \\
\hline
\end{tabular}

Sumber: Daftar Aset Tetap Peralatan dan Mesin Puskesmas Sugihmukti Kabupaten Bandung 2020 
Berdasarkan Tabel 2 di atas terlihat bahwa setiap tahun nilai barang mengalami peningkatan. Permasalahannya penambahan nilai ini tak lain disebabkan karena banyak barang yang rusak akan tetapi tidak dihapuskan karena sulitnya proses pengadministrasian penghapusan aset tersebut. Adapun daftar barang dengan kondisi rusak tetapi masih mempunyai masa manfaatnya yakni sebagai berikut.

Tabel 3. Jumlah Aset Tetap Peralatan dan Mesin dengan Kondisi Rusak pada Puskesmas Sugihmukti Kabupaten Bandung

\begin{tabular}{|c|c|c|c|c|c|}
\hline No & Tahun & & $\begin{array}{l}\text { Nama Barang dengan } \\
\text { Kondidi Rusak }\end{array}$ & $\begin{array}{c}\text { Masa } \\
\text { Manfaat } \\
\text { (Tahun) }\end{array}$ & Nilai \\
\hline \multirow[t]{3}{*}{1} & 2017 & - & Brand Kas & 5 & BMD. 4.644.172 \\
\hline & & - & Mesin Absensi & 5 & BMD. 1.702.500 \\
\hline & & - & P.C. Unit/Komputer PC & 5 & BMD. 15.428.455 \\
\hline 2 & 2018 & - & $\begin{array}{l}\text { Alat Kedokteran Umum } \\
\text { Lain-lain }\end{array}$ & 5 & BMD. 24.485.672 \\
\hline 3 & 2019 & - & Laptop & 5 & BMD. 4.074.744 \\
\hline
\end{tabular}

deskriptif adalah penelitian yang dilakukan terhadap variabel mandiri, yaitu tanpa membuat perbandingan dengan variabel lain. Penelitian ini dilakukan pada Puskesmas Sugihmukti Kabupaten Bandung. Penelitian dilakukan selama 1 Tahun dimulai dari Bulan Januari 2020 sampai Bulan Desember 2020. Bentuk pengumpulan data yakni berupa wawancara kepada 6 orang informan yang telah dilakukan secara purposif. Selain wawancara bentuk pengumpulan data lainnya berupa dokumentasi, observasi lapangan, dan triangulasi data. Adapun teknik analisis data yakni berupa reduksi data, penyajian data dan penarikan simpulan. Selanjutnya dari hasil analisis menggunakan tahapan editing, klasifikasi data, dan interpretasi.
Sumber: Bagian Tata Usaha, Bagian Aset Puskesmas Sugihmukti Kabupaten Bandung

Pada Tabel 3 dapat dilihat masih adanya beberapa barang yang mempunyai kondisi rusak akan tetapi masa manfaat dari barang tersebut masih ada, sehingga belum bisa dihapuskan dari daftar barang aset tetap peralatan dan mesin. Selain itu banyaknya barang yang rusak dan biaya pemeliharaan terbatas mengakibatkan barang-barang yang rusak tersebut disimpan di Gudang Permasalahan lain yang muncul yaitu pada Puskesmas Sugihmukti tidak adanya gudang untuk penyimpanan barang-barang rusak.

\section{METODE PENELITIAN}

Penelitian ini termasuk penelitian kualitatif deskriptif. Menurut Sugiyono (2013: 13) metode penelitian kualitatif

\section{HASIL PENELITIAN DAN PEMBAHASAN}

\section{Gambaran Umum Lokasi Penelitian}

Puskesmas Sugihmukti Kabupaten Bandung adalah salah satu unit pelaksana teknis pemerintah daerah di bidang kesehatan di bawah naungan Dinas Kesehatan Kabupaten Bandung yang bertanggung jawab memberikan pelayanan langsung kepada masyarakat.

Demi terciptanya pelayanan kepada masyarakat yang baik maka Puskesmas Sugihmukti mempunyai tugas memberikan upaya kesehatan yang menyeluruh secara profesional baik promotif, preventif dan kuratif, meningkatkan peran serta masyarakat untuk ikut serta untuk berperan aktif dalam upaya meningkatkan derajat kesehatan masyarakat di wilayah kerja 
Puskesmas Sugihmukti, meningkatkan derajat pengetahuan masyarakat tentang pola hidup sehat secara mandiri dan menjalankan prinsip-prinsip manajemen sejalan dengan tata kelola pemerintahan yang baik (good governance).

\section{Implementasi Kebijakan Pengelolaan BMD pada Puskesmas Sugihmukti Kabupaten Bandung}

Implementasi kebijakan pengelolaan Barang Milik Daerah (BMD) haruslah berjalan dengan baik sesuai dengan kebijakan pemerintah. Jika sudah berjalan dengan baik maka pengelolaan BMD dapat mewujudkan terciptanya good governance. Maka untuk mewujudkan good governance diperlukan lah sebuah pengukuran mengenai implementasi kebijakan dari suatu instansi khususnya Puskesmas Sugihmukti.

Penulis mengukur sejauh mana pengelolaan BMD berjalan dengan baik atau tidak dengan Teori Edwards III. Implementasi kebijakan merupakan kegiatan yang kompleks dengan begitu banyak faktor yang memengaruhi keberhasilan suatu implementasi kebijakan. Adapun untuk mengukur keberhasilan implementasi kebijakan publik meliputi 4 dimensi utama yaitu: 1) Komunikasi dengan indikator transmisi, konsistensi dan kejelasan; 2) Sumber-sumber dengan indikator staf, informasi, wewenang dan fasilitas-fasilitas; 3) Disposisi dengan indikator penempatan dan insentif, 4) Struktur Birokrasi dengan indikator prosedur kerja dan pragmatism. Adapun hasil di lapangan menunjukkan,

\section{- Komunikasi}

Salah satu dari indikator pengukur keberhasilan implementasi kebijakan menurut George Edwards III. Menjadi sangat penting dalam era sekarang di mana arus mobilisasi tinggi adalah ketetapan berkomunikasi. Ketetapan berkomunikasi di sini artinya bahwa pesan yang disampaikan dari komunikator ke komunikator harus jelas dan sesuai sehingga tidak timbul permasalahan baru seperti ketidakakuratan pesan dari kesalahan proses komunikasi.

Sesuai dengan operasional konsep yang telah dijelaskan sebelumnya, dimensi dari komunikasi yaitu transmisi, kejelasan, dan konsistensi.

\section{a) Transmisi}

Transmisi sebagai bagian dari komunikasi adalah proses pengangkutan informasi dari satu titik ke titik lain dalam satu jaringan. Satu pergerakan informasi melalui sebuah media telekomunikasi dengan memperhatikan pembuatan saluran yang dipakai untuk mengirim informasi, sehingga memastikan bahwa informasi sampai secara akurat dan diandalkan adalah proses transmisi. Keberhasilan indikator pengangkutan informasi yang dikaitkan di sini adalah bagaimana komunikasi dapat tersampaikan ke beberapa lapisan hierarki birokrasi.

Pada Puskesmas Sugihmukti Kabupaten bandung komunikasi dilakukan melalui beberapa lapisan hierarki birokrasi. Adapun proses hierarki tersebut dilakukan oleh lapisan-lapisan birokrat. Perencanaan pengelolaan Barang Milik Daerah pada Puskesmas biasanya pertama menggunakan sistem top-down atau yakni komunikasi dilakukan dari hierarki teratas dilanjutkan ke hierarki terbawah. Awal komunikasi yakni ketika Kepala Puskesmas diinformasikan dan disosialisasikan untuk membuat perencanaan dengan pagu anggaran yang telah ditentukan oleh Seksi Perencanaan.

Akan tetapi permasalahannya dari Seksi Perencanaan langsung menginformasikan instruksi pembuatan perencanaan anggaran biaya langsung ke Kepala Puskesmas dan Akuntan yang melewati beberapa hierarki birokrat yaitu Bendahara Pengeluaran dan Bendahara Barang Milik Daerah/Aset.

Terlewatinya beberapa hierarki birokrasi ini menimbulkan ketidaktahuan atau terjadi miss komunikasi antara Bendahara 
Pengeluaran dan Bendahara Barang. Seperti yang dikatakan Kepala Puskesmas, Redy Hanida. Beliau mengatakan bahwa:

"Pada perencanaan penganggaran biaya pengelolaan Barang Milik Daerah sering terjadi mis komunikasi karena kurangnya sosialisasi terutama pada awal-awal perencanaan. Seksi perencanaan sering menginformasikan mengenai pagu anggaran hanya kepada saya dan akuntan tanpa diinformasikan kepada Bendahara Pengeluaran dan Bendahara Barang." (Wawancara, 31 Agustus 2020)

Berdasarkan hasil wawancara tersebut di atas dapat dilihat bahwa penyebab miss komunikasiyaitu karena kurangnya sosialisasi pada awal perencanaan. Seksi perencanaan hanya menginformasikan mengenai pagu anggaran kepada Kepala Puskesmas dan Akuntan tanpa menginformasikan pagu anggaran kepada Bendahara Pengeluaran dan Bendahara Barang.

Sejalan dengan hal tersebut Edwards III pun memaparkan bahwa ada beberapa hambatan yang timbul dalam mentransmisikan perintah-perintah implementasi, yaitu: 1) Pertentangan pendapat antara pelaksana dengan perintah yang dikeluarkan oleh pengambil kebijakan; 2) Informasi melewati berlapis-lapis hierarki birokrasi; dan 3) Perbedaan persepsi dalam menangkap atau menerjemahkan persyaratan-persyaratan suatu kebijakan.

Melihat apa yang telah dipaparkan oleh Edwards III, penulis melihat hambatanhambatan yang terjadi pada Puskesmas Sugihmukti yakni adanya miss komunikasi. Miss komunikasi ini terjadi karena informasi yang disampaikan terlewati berlapislapis hierarki birokrasi yakni Bendahara Pengeluaran, Bendahara BMD

\section{b) Konsistensi}

Konsistensi atau keseragaman dari ukuran dasar dan tujuan perlu dikomunikasikan sehingga implementator mengetahui secara tepat ukuran maupun tujuan kebijakan itu. Komunikasi dalam organisasi merupakan suatu proses yang amat kompleks dan rumit seperti informasi mengenai pengelolaan Barang Milik Daerah (BMD) yang sering kali tidak jelas arahnya. Ketika kebijakan pembuatan perencanaan perbelanjaan BMD diinformasikan harus berdasarkan SSH (Standar Satuan Harga) akan tetapi ketika barang yang telah direncanakan dan sesuai dengan $\mathrm{SSH}$ tersebut berbeda. Barang yang dipesan banyak yang tidak sesuai dengan Surat Pesanan (SP). Sehingga dalam hal ini adanya ketidakkonsistenan antara SP dengan barang yang datang.

Hal ini seperti pengakuan Kepala Puskesmas Sugihmukti, Redy Hanida, beliau mengatakan:

"Kami merencanakan barang yang akan dibelanjakan yang telah tertera pada rencana biaya anggaran (RBA) dan sesuai instruksi dan informasi Seksi Perencanaan yang harus sesuai SSH. Akan tetapi kebanyakan barang yang dipesan melalui Surat Pesanan (SP) tidak sesuai. Ketika kami belanja kepada pihak ketiga (Pihak yang Membelanjakan Kebutuhan) itu menggunakan Surat Pesanan apa yang mau dibelanjakan, spesifikasi barang, serta harga barang pun kami cantumkan pada Surat Pesanan tersebut,akan tetapi kenyataannya pihak ketiga memberikan barang yang kami butuhkan, namun spesifikasi dan harga barang pun tidak sesuai dengan apa yang kami harapkan. Pihak ketiga menjelaskan kepada kami bawasannya barang yang telah dipesan dengan spesifikasi yang telah diajukan tersebut harga barangnya telah berubah menjadi tinggi, sehingga pihak ketiga pun memberikan barang yang dibutuhkan dengan menurunkan spek yang ada agar harga masuk sesuai SSH. Jujur ini membuat kami kecewa akan tetapi bagaimana lagi kalau SSH-nya sudah 
tidak sesuai dengan keadaan di lapangan dan tidak update kami tidak bisa berbuat apa-apa karena SSH sifatnya baku dan tidak bisa dirubah. Kami pun terpaksa mengikuti harga SSH meskipun barang yang datang tidak sesuai. Daripada menyalahi aturan lebih baik seperti itu." (Wawancara, 31 Agustus 2020)

Berdasarkan hasil wawancara tersebut penulis menyimpulkan bahwa Puskesmas Sugihmukti adanya ketidakkonsistenan komunikasi terlihat ketika Puskesmas Sugihmukti telah merencanakan barang yang akan dibelanjakan sesuai dengan rencana biaya anggaran (RBA) dan SSH. Namun kebanyakan barang yang kami pesan melalui Surat Pesanan (SP) tidak sesuai. Terlihat ketika belanja kepada pihak ketiga (Pihak yang Membelanjakan Kebutuhan) menggunakan Surat Pesanan yang di dalamnya tertera spesifikasi barang, serta harga akan tetapi pada kenyataannya pihak ketiga memberikan barang dengan spesifikasi dan harga yang tidak sesuai dengan SP, ini dikarenakan terdapat perbedaan antara spesifikasi dan harga barang di lapangan dengan SHH. Sehingga pihak ketiga memberikan barang dengan menurunkan spesifikasi yang ada supaya harga masuk sesuai SSH dan tidak menyalahi aturan yang berlaku.

Hasil yang ditemui di lapangan pun sejalan dengan pendapat Edwards III bahwa "Jika implementasi kebijakan ingin berjalan dengan efektif, maka perintah-perintah pelaksanaan harus konsisten dan jelas. Di samping itu perlu dihindari adanya perintahperintah yang bertentangan satu sama lain"

Sejalan dengan pendapat Edwards III pada Puskesmas Sugihmukti mendapati pertentangan satu sama lain, ini terlihat ketika RBA dibuat harus sesuai dengan SSH, akan tetapi SSH yang ada tidak sesuai dengan kondisi lapangan, sedangkan dalam pemberkasan perbelanjaan apa yang dibelanjakan harus sesuai dengan RBA.

\section{c) Kejelasan}

Informasi yang disampaikan sudah cukup jelas tersampaikan. Kejelasan ini terlihat ketika Kepala Puskesmas menyampaikan hal-hal apa yang harus dikerjakan kepada Bendahara Pengeluaran, Bendahara Barang dan Akuntan mengenai Pengelolaan Barang Milik Daerah. Kejelasan ini tertuang pada Tugas Pokok dan Fungsi setiap stakeholders pengelola Barang Milik Daerah Hal ini seperti yang disampaikan Kepala Puskesmas Sugihmukti, Redi Hanida menjelaskan:

"Pada pengelolaan Barang Milik Daerah setiap stakeholders sudah mengetahui apa yang harus mereka kerjakan, adanya uraian tugas pokok dan fungsi ini setiap stakeholders yang mengelola Barang Milik Daerah diharapkan dapat mengelola dengan baik. Akan tetapi permasalahannya sering kali apa yang tertera dalam tugas pokok dan fungsi ini tidak berjalan dengan baik dikarenakan keterbatasan SDM untuk pengelolaan BMD. Ini disebabkan karena adanya rangkap-rangkap jabatan pada Bendahara yang mengelola BMD baik Bendahara Pengeluaran maupun Bendahara BMD." (Wawancara, 31 Agustus 2020)

Dalam hal ini terlihat kejelasan komunikasi telah tersampaikan dengan baik dengan menuangkan tugas pokok dan fungsi pada setiap pegawai khususnya pengelola BMD yang di dalamnya memuat hal-hal apa yang menjadi tanggung jawab dan mesti dikerjakan. Namun permasalahan yang terjadi yakni pada staf yang ada karena adanya rangkap-rangkap jabatan pada pengelola BMD.

\section{- Sumber-Sumber}

Tidak hanya bertumpu pada komunikasi sebagai penentu keberhasilan implementasi kebijakan, Edwards III juga mengungkapkan 
bahwa sumber daya pelaksana kebijakan menjadi tolak ukur bagaimana kebijakan memberikan manfaat ketika diterapkan.

\section{a) Staf}

Pada pengelolaan BMD staf di Puskesmas Sugihmukti banyak yang tidak sesuai dengan latar belakang pendidikannya. Kebanyakan stafnya berlatar pendidikan fungsional bidang kesehatan. Dalam pengelolaan BMD pun dilakukan oleh Bendahara Pengeluaran yang berlatar belakang pendidikan diploma kebidanan, Bendahara Barang Milik Daerah berlatar belakang pendidikan sarjana terapis gigi dan hanya akuntan yang linier dengan tugasnya, yakni sarjana terapan akuntansi.

Tabel 4 Daftar Nama Pengelola Barang Milik Daerah Tahun 2020

\begin{tabular}{clll}
\hline No & \multicolumn{1}{c}{ Nama } & \multicolumn{1}{c}{ Jabatan } & Pendidikan \\
\hline 2 & Jajang Jatnika, & Kepala & S-1 Sosiologi \\
& S.Sos & Subag TU & \\
3 & $\begin{array}{l}\text { Yuyun } \\
\text { Yuningsih, A.Md. }\end{array}$ & $\begin{array}{l}\text { Bendahara } \\
\text { Pengeluaran }\end{array}$ & D-III \\
& Keb & & \\
4 & Rohmat, S.Tr.Kes & Bendahara \\
& & BMD & S-1 Terapan \\
& & Kesehatan \\
& & Masyarakat \\
5 & Shelly Putri & Akuntan & S-1 Terapan \\
& Karina, S.Tr. & & Akuntansi \\
& Akun & & \\
\hline
\end{tabular}

Sumber: Puskesmas Sugihmukti Tahun 2020

Berdasarkan data tersebut banyaknya pengelola BMD yang tidak linier dengan pendidikannya sehingga perlu adanya pelatihan untuk menyeimbangkan kinerja dengan keahlian. Sejalan dengan hal tersebut Jajang Jatnika selaku Kepala Sub Bagian Tata Usaha menjelaskan,

"Mengenai pelatihan telah ada anggrannya yang tertera dalam Rencana Biaya Anggran (RBA). Bahkan untuk tahun ini telah dianggarkan BMD. 38.000.000,- akan tetapi pelatihannya belum dilakukan karena terhalang oleh pandemik Covid-19. Adanya anggaran serta pelatihan kepada bendaharabendahara dalam mengelola BMD tak lain diharapkan nantinya dapat menstabilkan kemampuan dalam pengelolaan BMD meskipun latar belakang pendidikan pengelola BMD tidak linier dengan jabatan yang diembannya." (Wawancara, 26 Agustus 2020)

Hasil yang didapat dalam wawancara yang dilakukan dengan Kepala Sub Bagian Tata Usaha ini yakni dalam pengelolaan BMD khususnya pada penatausahaan barang masih belum berjalan dengan baik karena adanya keterbatasan SDM sehingga yang berlatar belakang pendidikan pun harus mengelola BMD. Pada permasalahan tersebut Puskesmas Sugihmukti mengupayakan dengan adanya anggaran untuk pelatihan yang diharapkan dapat menstabilkan kemampuan dalam pengelolaan BMD.

\section{b) Informasi}

Dalam pengelolaan Barang Milik Daerah setiap stakehoders pengelola BMD adanya kesalahan-kesalahan administratif yakni adanya status penggunaan barang ganda. Berdasarkan wawancara dengan Bendahara Barang Puskesmas Sugihmukti, Rohmat beliau mengatakan,

"Dalam status penggunaan barang ganda pada Puskesmas Sugihmukti Kabupaten Bandung masih ada, ini terlihat pada Speda Motor dengan nomor polisi D 5278 S dan D $2727 \mathrm{~V}$ menggunakan Kode Barang 02.03.01.05.0001 Register 0001 dan 0002 tetapi penggunaannya oleh orang yang sama. Sehingga dalam hal ini perlu adanya perbaikan informasi laporan pemindahtanganan salah satu Barang Milik Daerah tersebut supaya tidak terjadi penggunaan barang ganda dalam laporan-laporan BMD. Laporanlaporan BMD ini nantinya akan dijadikan sebagai dasar pemeriksaan BPK 
(Badan Pengawas Keuangan). Ketika adanya informasi bahwa laporan BMD pada Puskesmas Sugihmukti terdapat penggandaan penggunaan barang maka nantinya Puskesmas Sugihmukti akan memicu pemeriksaan BPK yang melanggar asas efisiensi BMD. Namun pada kenyataannya salah satu motor telah dipindahtangankan." (Wawancara, 26 Agustus 2020)

Berdasarkan hasil wawancara tersebut di atas pada Puskesmas Sugihmukti Kabupaten Bandung masih terdapat kesalahan informasi yakni pada Speda Motor dengan nomor polisi D 5278 S dan D 2727 V menggunakan Kode Barang 02.03.01.05.0001 Register 0001 dan 0002 tetapi penggunaannya oleh orang yang sama. Mengenai permasalahan ini perlu adanya perbaikan informasi laporan pemindahtanganan salah satu Barang Milik Daerah tersebut supaya tidak melanggar asas efisiensi BMD. Akan tetapi pada kenyataanya salah satu motor telah dipindahtangankan.

\section{c) Wewenang}

Wewenang dalam Pengelolaan BMD lebih ditujukan kepada Bendahara BMD/Aset serta Kepala Puskesmas melalui Surat Keputusan (SK). Bendahara BMD/Aset pada wewenangnya disebut Pembantu Pengurus Barang. Adapun SK untuk Pembantu Pengurus Barangyakni melalui Keputusan Kepala Dinas Kesehatan Kabupaten Bandung Nomor P/800/4213/ II/2020/DINKES tentang Penunjukan Tugas Pembantu Barang di Lingkungan Dinas Kesehatan Kabupaten Bandung Selain itu untuk Kepala Puskesmas pada wewenangnya disebut Kuasa Pengguna Anggaran/Kuasa Pengguna Barang. Adapun SK Kuasa Pengguna Barang/Kuasa Pengguna barang yakni melalui penerbitan Keputusan Bupati Bandung No. 954/Kep.05-Dinkes/2020 tentang Penunjukan Pengelola Keuangan Daerah pada Dinas Kesehatan Tahun Anggaran 2020. Adapun penjelasan mengenai Kuasa Pengguna Barang dipaparkan oleh Kepala Puskesmas Sugihmukti, Redi Hanida:
"Adanya SK yang dikeluarkan oleh Bupati Kabupaten Bandungmenjadikemudahan dalam pengelolaan keuangan dan aset karena sebagai payung hukum dalam leluasa menjalankan kewenangan saya sebagai kuasa pengguna anggaran/ kuasa pengguna barang." (Wawancara, 31 Agustus 2020)

Berdasarkan hasil wawancara dan data SK yang ada maka penulis menganalisis bawasannya kewenangan-kewenangan pembantu pengurus barang dan kuasa pengguna anggaran adalah mengelola BMD yang tak lain sebagai modal utama berjalannya sebuah kegiatan operasional kegiatan di Puskesmas Sugihmukti. Adapun dengan adanya SK yang dikeluarkan oleh Kepala Dinas Kesehatan Kabupaten Bandung dan Bupati Kabupaten Bandung adalah sebagai payung hukum dalam menjalankan wewenang-wewenang pembantu pengurus barang dan kuasa pengguna anggaran/kuasa pengguna barang.

\section{d) Fasilitas-fasilitas}

Edwards III memaparkan fasilitas yakni sarana dan prasarana yang dibutuhkan untuk mengimplementasikan kebijakan publik. Berdasarkan hasil wawancara dengan Akuntan Puskesmas Sugihmukti, Shelly Putri Karina yang memaparkan bahwa:

"Puskesmas Sugihmukti fasilitas-fasilitas yang ada di Puskesmas Sugihmukti yakni terdiri dari : 1) Barang dan jasa yang meliputi alat tulis kantor (ATK), alat listrik, prangko, peralatan dan bahan kebersihan, bbm, pengisian tabung gas, peralatan rumah tangga, peralatan komputer, bahan baku bangunan, obatobatan, bahan baku kegiatan, listrik dan internet, jasa pelayanan kesehatan, asuransi pegawai, biaya pemeliharaan kendaraan, cetak dan penggandaan, anggaran sewa gudang, anggaran sewa bis, mamin kegiatan, pakaian kerja, perjalanan dinas, anggaran 
kursus, pelatihan dan bimbingan teknis, anggaran pemeliharaan alat laboratorium, jasa pemusnah sampah rumah tangga dan sampah medis; dan 2) Modal yang terdiri dari tersedianya laptop, printer, hardisk, wifi, ac, alat-alat kesehatan dan laboratorium, meubelair, kendaraan dinas, dan tersedianya gedung dan bangunan." (Wawancara, 26 Agustus 2020)

Fasilitas-fasilitas yang ada di Puskesmas Sugihmukti banyak dan telah terpenuhi untuk bekerja. Akan tetapi masih adanya fasilitas yang kurang dimiliki oleh Puskesmas Sugihmukti yakni belum adanya gudang kotor, seperti hasil wawancara penulis dengan Bendahara Barang Puskesmas Sugihmukti, Rohmat beliau menjelaskan:

"Banyaknya barang yang rusak dan biaya pemeliharaan telah habis maka barang-barang yang rusak tersebut sering disimpan di gudang kotor Permasalahannya yaitu pada Puskesmas Sugihmukti hanya memiliki satu gudang difungsikan untuk menyimpan obat-obatan." (Wawancara, 26 Agustus 2020).

\section{- Disposisi}

\section{a) Penempatan}

Edwards III mengemukakan bawasannya pemilihan dan penempatan pegawai pelaksana kebijakan haruslah orang-orang yang memiliki dedikasi terhadap kebijakan yang telah ditetapkan.

Berdasarkan hasil wawancara dengan Bendahara Barang, Rohmat didapatkan informasi bahwa,

"Saya tetap menjalankan penempatan pekerjaan yang diberikan pimpinan kepada saya meskipun saya harus merangkap pekerjaan namun saya tetap berusaha memberikan yang terbaik terhadap pekerjaan saya sebagai perawat gigi dan sebagai bendahara BMD." (Wawancara, 26 Agustus 2020)

Hal senada dikatakan oleh Yuyun Yuningsih selaku Bendahara Pengeluaran Puskesmas Sugihmukti didapatkan informasi bahwa,

"Penempatan pekerjaan yang diberikan pimpinan kepada saya tetap saya jalankan meskipun saya harus merangkap pekerjaan yang terkadang harus banyak membagi waktu antarsatu pekerjaan dengan pekerjaan lainnya namun saya tetap berusaha untuk memenuhi kewajiban saya sebagai bidan dan sebagai bendahara pengeluaran." (Wawancara, 26 Agustus 2020)

Berdasarkan hasil wawancara yang didapati dari Bedahara Barang dan Bendahara Pengeluaran penempatan posisi di Puskesmas Sugihmukti secara umum dalam hal pekerjaan sudah berjalan dengan baik terlihat ketika Bendahara Barang tetap menjalankan penempatan pekerjaan yang diberikan pimpinan meskipun harus merangkap pekerjaan, namun tetap berusaha memberikan yang terbaik terhadap pekerjaan yakni Bendahara Barang merangkap pekerjaan sebagai perawat gigi dan sebagai Bendahara BMD. Selain Bendahara Pengeluaran yang merangkap pekerjaan sebagai Bendahara Pengeluaran dan Bidan. Usaha yang dilakukan supaya pekerjaan sebagai pengelola BMD yakni dengan membagi waktu antarsatu pekerjaan dengan pekerjaan lainnya.

\section{b) Insentif}

Selain dengan penempatan pegawai yang sesuai dan memeiliki persepsi atau sikap yang sama dengan pembuat program atau kebijakan guna mencapai tujuan yang ditetapkan maka salah satu yang juga berpengaruh terhadap sikap dan komitmen pelaksana yaitu dengan pemberian insentif yang sesuai. Tidak dapat dipungkiri bahwa sikap dan komitmen pelaksana dapat 
ditingkatkan dengan upaya pemberian insentif yang mencukupi.

Berdasarkan pernyataan Jajang Jatnika selaku Kepala Sub Bagian Tata Usaha beliau menyatakan,

"Di Puskesmas Sugihmukti pemberian insentif pengelola BMD dari anggaran Badan Layanan Umum Daerah (BLUD) yang dituangkan pada Jasa Pelayanan Kesehatan di mana setiap pekerjaan dengan jabatannya akan diberikan point. Semakin banyak yang dikerjakan sesuai jabatannya maka akan semakin banyak pula poin yang didapat yang nantinya berpengaruh terhadap besaran insentif yang diberikan." (Wawancara, 26 Agustus 2020)

Berdasarkan hasil wawancara tersebut maka penulis menganalisis bawasannya pada Puskesmas Sugihmukti mengelola Barang Milik Daerah mendapatkan insentif. Pemberian insentif pengelola BMD dari anggaran Badan Layanan Umum Daerah (BLUD) yang dituangkan pada Jasa Pelayanan Kesehatan di mana setiap pekerjaan dengan jabatannya akan diberikan point. Setiap point akan menjadi dasar besarnya penerimaan insentif yang didapatkan sehingga semakin banyak yang dikerjakan sesuai jabatannya maka akan semakin besar pula poin dan besaran insentif yang diterima.

\section{- Struktur Birokrasi}

\section{a) Prosedur Kerja}

Setiap instansi pemerintahan di dalam menjalankan roda pemerintahannya telah memiliki Standar Operasional Prosedur (SOP) dan struktur penyelenggaraan birokrasi tersebut. SOP sangat diperlukan sebuah lembaga untuk menjelaskan tentang sistematika program dan alur pelaksanaan program tersebut karena hal ini menjadi dasar penyelenggaraan pemerintah untuk memberikan transparansi kepada publik.
Tabel 5 Daftar SOP yang Ada di Puskesmas Sugihmukti Tahun 2020

\begin{tabular}{|c|c|c|}
\hline No & SOP & Keterangan \\
\hline 1 & $\begin{array}{l}\text { SOP Penentuan Faktor Resti } \\
\text { untuk Ibu Hamil }\end{array}$ & Dilaksanakan \\
\hline 2 & SOP Penerimaan Pasien Baru & Dilaksanakan \\
\hline 3 & $\begin{array}{l}\text { SOP Melakukan Suntikan } \\
\text { Subcutan }\end{array}$ & Dilaksanakan \\
\hline 4 & SOP Suntikan Intra Muskuler & Dilaksanakan \\
\hline 5 & $\begin{array}{l}\text { SOP Penatalaksanaan Syok } \\
\text { Aanafilaktik }\end{array}$ & Dilaksanakan \\
\hline 6 & $\begin{array}{l}\text { SOP Pemberian Imunisasi } \\
\text { DPT, BCG, Campak, Tetanus } \\
\text { Tozoid, dan Polio }\end{array}$ & Dilaksanakan \\
\hline 7 & $\begin{array}{l}\text { SOP Bimbingan Cara Menyu- } \\
\text { sui yang Baik }\end{array}$ & Dilaksanakan \\
\hline 8 & SOP Pemasangan Infus & Dilaksanakan \\
\hline 9 & $\begin{array}{l}\text { SOP Pemeriksaan Denyut } \\
\text { Jantung }\end{array}$ & Dilaksanakan \\
\hline 10 & SOP Pemeriksaan Kehamilan & Dilaksanakan \\
\hline 11 & $\begin{array}{l}\text { SOP Pengisian Kartu Bayi, } \\
\text { Anak dan Ibu Hamil }\end{array}$ & Dilaksanakan \\
\hline 12 & $\begin{array}{l}\text { SOP Pencabutan Gigi Anak } \\
\text { dan Dewasa }\end{array}$ & Dilaksanakan \\
\hline 13 & $\begin{array}{l}\text { SOP Penerimaan Pegawai } \\
\text { Baru }\end{array}$ & Dilaksanakan \\
\hline 14 & $\begin{array}{l}\text { SOP Pembuatan Visum Pega- } \\
\text { wai }\end{array}$ & $\begin{array}{l}\text { Belum Dilak- } \\
\text { sanakan }\end{array}$ \\
\hline 15 & $\begin{array}{l}\text { SOP Pembuatan Surat Per- } \\
\text { jalanan Dinas, Cuti, Izin dan } \\
\text { Sakit }\end{array}$ & Dilaksanakan \\
\hline 16 & $\begin{array}{l}\text { SOP Pemeliharaan Alat Kan- } \\
\text { tor }\end{array}$ & Dilaksanakan \\
\hline 17 & $\begin{array}{l}\text { SOP Penatausahaan Ba- } \\
\text { rang-barang Milik Daerah }\end{array}$ & $\begin{array}{l}\text { Belum Dilak- } \\
\text { sanakan }\end{array}$ \\
\hline
\end{tabular}

Sumber: Puskesmas Sugihmukti Tahun 2020

Berdasarkan data tersebut salah satu SOP yang belum dilaksanakan oleh Puskesmas Sugihmukti yakni mengenai SOP Penatausahaan Barang-Barang Milik Daerah.

\section{b) Pragmatisme}

Pragmatisme pada Puskesmas Sugihmukti tidak terjadi karena Puskesmas 
Sugihmukti yakni puskesmas dengan penggunaan anggaran BLUD (Badan Layanan Umum Daerah) yang telah ditetapkan oleh Peraturan Bupati Bandung No. 17 Tahun 2015 tentang Standar Pelayanan Minimal pada BLUD UPTD Pelayanan Kesehatan di Kabupaten Bandung. Di mana dalam pelaksanaannya harus mengurus rumah tangganya sendiri. Artinya perencanaan dilakukan secara intern tanpa pengaruh dari pihak lain, selain itu dalam pelaksanaan dilakukan secara mandiri akan tetapi dalam pengevalusian melakukan sendiri dan di bawah evaluasi Dinas Kesehatan, BPKP, serta BPK.

Adapun hasil wawancara dengan Kepala Puskesmas Sugihmukti, Redy Hanida, beliau memaparkan:

"Pada Puskesmas Sugihmukti menggunakan anggaran BLUD (Badan Layanan Umum Daerah). Sehingga tidak adanya pengaruh pihak lain yang ikut andil." (Wawancara, 31 Agustus 2020)

\section{SIMPULAN}

Berdasarkan pembahasan mengenai analisis masalah yang terdapat di lapangan maka dapatdisimpulkanbahwaimplementasi kebijakan pengelolaan Barang Milik Daerah (BMD) pada Puskesmas Sugihmukti sudah berjalan namun belum optimal. Hal ini dapat terlihat dari belum terpenuhinya indikator implementasi kebijakan yang mengacu pada teori Edwards III.

Pertama, dalam hal komunikasi transmisi sering terjadinya miss komunikasi antarbirokrat pengelola BMD terkait pagu anggaran yang ada selain itu adanya ketidakkonsistenan informasi yang dapat terlihat ketika penganggaran barang tidak sesuai dengan Surat Pesanan (SP).
Kedua, mengenai sumber-sumber yakni adanya ketidaklinieran Pendidikan pengelola BMD. Ketiga, mengenai informasi terlihat adanya kesalahan informasi di mana adanya kesalahan informasi kepemilikan barang ganda. Keempat, mengenai fasilitas-fasilitas yaitu belum adanya gudang kotor. Selain itu mengenai fasilitas yakni belum adanya SOP penatausahaan barang

\section{SARAN}

Saran yang diberikan penulis untuk menjawab permasalahan terkait adalah sebagai berikut.

\section{Komunikasi}

Harus adanya group whatsapp dalam sistem komunikasi top-down dan harus adanya negosiasi yang dilakukan pihak Puskesmas kepada Pembuat serta penyusun SSH untuk memperbaharui SSH sesuai keadaan di lapangan

\section{Sumber-sumber}

Harus adanya pelatihan berkala pada Bendahara BMD dan Bendahara Pengeluaran. Selain itu untuk informasi laporan SIMDABMD saranyangdiberikan yaitu dengan mengoordinasikan kepada pihak Aset Kabupaten Bandung supaya aplikasinya dapat diperbaharui. Adapun untuk fasilitas saran yang diberikan adalah penyewaan gudang yang dekat dengan kantor Puskesmas Sugihmukti.

\section{Disposisi}

Harus adanya insentif jika pekerjaan dilaksanakan serta harus adanya sanksi jika pekerjaan tidak dilaksanakan.

\section{Struktur Birokrasi}

Harus adanya pelatihan berkala serta insentif yang memicu motivasi dalam penuntasan pekerjaan. 


\section{DAFTAR RUJUKAN}

Ilham, Muh dan Murliasari, Rikha. 2015. Permodelan Kebijakan. Jatinangor: Buku Literatur IPDN.

Sholeh, Chabib dan Rochmansjah,Heru. 2010. Pengelolaan Keuangan dan Aset Daerah Sebuah Pendekatan Struktural Menuju Tata Kelola Pemerintahan yang Baik. Bandung: Fokusmedia.
Sugiyono. 2013. Metode Penelitian Kuantitatif dan Kualitatif Metode R\&D. Bandung: Alfabeta

Peraturan Pemerintah No 27 Tahun 2014 tentang Pengelolaan Barang Milik Daerah 